\title{
Islamic Triangle Concept of Marital Age: Indonesian Experience
}

\author{
Fauzan Muhammadi ${ }^{*}$, Eva Wulandari ${ }^{2}$, M. Hajir Susanto ${ }^{3}$
}

1,2,3 Faculty of Law, Department of Law, Universitas Ahmad Dahlan, Yogyakarta, 55166, Indonesia

* Corresponding author: fauzan.muhammadi@law.uad.ac.id

\begin{tabular}{|c|c|}
\hline Article & Abstract \\
\hline $\begin{array}{l}\text { Article History } \\
\text { Received: Nov 5, 2020; } \\
\text { Reviewed: Nov 10, 2020; } \\
\text { Accepted: May 21, 2021; } \\
\text { Published: May 30, } 2021\end{array}$ & $\begin{array}{l}\text { Marriage is a sacred act that no one will doubt. The sacredness of marriage does } \\
\text { not mean that every person could be married. There are legal competences in Islam } \\
\text { that every person should be aware of before doing any legal acts. Islamic law sets } \\
\text { two indicators of legal age; both are bälig and rusydan. Indonesia has determined } \\
\text { the age of } 19 \text { to be a formal legal age of Indonesian people for their marriage. } \\
\text { Finding the connection between the two indicators and concluded age is worth } \\
\text { studying. The article aims to correlate Islamic legal competence with the marriage } \\
\text { readiness and triangle analysis of legal age marriage based on Indonesia's factual } \\
\text { issues. The article was described and analyzed qualitatively and based on the } \\
\text { normative legal review. The review found out that abliyyatul adä al-kämilah is } \\
\text { the appropriate phase-in doing all legal activities, including marriage. The } \\
\text { concluded-age of } 19 \text { by the Indonesian government is well-measured when it was } \\
\text { analyzed through the three parallel concepts: maslabah, ra'iyyatul imam manütun } \\
\text { bil maslabah, and sadd al-zariah, all of which allow valuable considerations based } \\
\text { on actual problematic issues of underage marriage. }\end{array}$ \\
\hline \multicolumn{2}{|c|}{$\begin{array}{l}\text { (C)2021; This is an Open Access Research distributed under the term of the Creative Commons } \\
\text { Attribution License (https://Creativecommons.org/licences/by/4.0), which permits unrestricted } \\
\text { use, distribution, and reproduction in any medium, provided the original works are appropriately } \\
\text { cited. }\end{array}$} \\
\hline
\end{tabular}

\section{INTRODUCTION}

It is generally acceptable that marriage in Islam is a sacred sexual relationship between men and women (Hori \& Cipta, 2019), a physical intimacy that everyone should go through legally (natural human activity and Islamic tradition) (Zaman \& Hashmi, 2019). Additionally, it is not just a merely physical relationship but also a form of worship to the Creator (Sialvi, 2018). Thus, cohabitation and sexual intercourse outside the marital ties are considered as wrongdoings and subject to sanction. 
The marriage bears two social consequences; both are material and immaterial, where the former relates to demographic features in which reproduction through marital relationships preserves humans from extinction. In comparison, the immaterial part refers to religious feeling; of worshiping Allah through marriage (Zarean \& Barzegar, 2016). The married-couple would not only seek to love each other but also obey the divine rule from Allah. The population feature is in line with what the Quran (4:1) says that humans created from one single soul and sourced from this soul are its couple then disperse from both many men and women. Through this verse, we could realize that sharia objectives of marriage are to be well-ordered as they love each other and be a fair posterity one after another (Khoiruddin, Rohimin, \& Athoillah, 2019). Muhammad the Prophet also said in his statement that marriage is his legal tradition. He said that marrying someone is even accomplishing half of faith (Zaki, 2017). That is, the marital connection between men and women is inner religious-social engagement. The immaterial feature also plays a role in marital satisfaction (Sorokowski et al., 2017) because it correlates to obeying Allah's divine command.

Although marriage is the divine order for all Muslims, in this concept, of course, not all persons are feasible to get married legally. Those who are willing to get married need to be legally competent. Islam talks about competency in all its laws in a term of balig. The ballig condition would be one of the conditions the couples must acquire. However, Islam does not explicitly mention the age of bälig (Kamarusdiana \& Sofia, 2020). The concept is usually refers to the biological condition between men and women. A boy reaches the state of bãlig when he gets his first wet dream (ihbtiläm). It is a circumstance when he ejaculates in his sleep. While in women's condition, bälig is marked by first menstruation (Shahar, 2018).

Classically, Islamic scholars are not in agreement when these circumstances occur. Syafii School and Hanbali School imply that men and women are mature at the age of 15. In contrast, Hanafi School considers age 18 for males and 17 for females (Kamarusdiana \& Sofia, 2020). In contrast, Maliki School implies that bälig is at the age of 18 for both sexes (Sitorus \& Yusmita, 2020). Nowadays, determining bälig: involves physical and biological maturation and psychological readiness, indicated by mental and emotional growth. Claudia Seise sees the two conditions as split liminality (Seise, 2019). Through this split, every state tries to set the age everyone should reach for marrying.

As one of the countries with the biggest Muslim population in the world, Indonesia has set age limit at which someone is allowed to get married. There are two significant regulations serving as the basis: the Marriage Act No. 1 of 1974 requiring a person to be at least 19 and 16 years old to get married for male and female respectively and the Marriage Act No. 16 of 2019 requiring either male or female to be 19 as the minimum age. Despite the age regulated in these two acts, underage marriage is still common in Indonesia. Statistically, those who got married before the age accounted 
for $24 \%$ in 2013, and it decreased less than a half percent in 2014. In 2015, the percentage insignificantly declined by one percent. In the next few years of the report, the figures were lower than in previous years (Badan Pusat Statistik, 2017). By 2016, the marriage before the age of 18 is accounted for $11.11 \%$. before it rose to $11.54 \%$ in 2017 and slightly decreased in the following year by 11.21\% (Badan Pusat Statistik, 2020). Despite these figures, the benchmark of legal age that allows marriage still remains unknown in Indonesia.

Setting the legal age of marriage is the main focus of this article where two essential questions are raised. First, how is the legal competence in Islamic law? Second, how does the state set the minimum marital age viewed from Islamic triangle concept? Through these two questions, this study aims to understand legal competence, for it will become the measurement of every human activity. Besides, the question of, "is it right for the state to set the legal age, while Islam only says bälig," in this study is intended to show the relation between the setting of the minimum legal age of marriage and triangle concept of mashla $\underline{b} a h$, ra'iyyatul imam manütun bil maslabah, and sadd al-zari’ah.

This study is expected to develop the Islamic law approach en to determination of state's policy, especially regarding how the Muslim legal academicians should employ the triangle singularity more often for generating legal policy. Using this concept would likely provide the wide-ranging assessment in formulating the ongoing possibilities in legal change. The experience of Indonesian Government to determine the minimum marital age could be enhanced and it is worth observing.

\section{METHOD}

This is a normative research or legal doctrinal research, a legal study for developing and conceptualizing the law based on a certain doctrine. This normative study managed with conceptual approach based on the various legal concepts. (Irwansyah, 2020). Because it is not an empirical one, the data sources came from primary and secondary material supply. The primary material sources were gathered from Quran and Hadiths alongside with several ef Indonesia's Acts. The other sources in this article were taken from QS. Al-Nisa: 1 and 6, while the hadith was taken from al-Bukhari's hadith compilation, specifically in "The insane are not meant to be stoned" section (Al-Asqalani, n.d.). Alongside with previous two sources are two Indonesia's Acts: The Marriage Act No. 1 of 1974 and The Marriage Act No. 16 of 2019. Beside the primary legal material, there is some secondary data obtained from various literal documentation, such as books, journals, and theses. The all obtained data was analyzed descriptively through qualitative method. It means that all gathered information was organized and mapped to find the most important feature to be discussed and to present it in a narrative form (Anggito \& Setiawan, 2018). The analysis is was also supplemented by mashla $\underline{b a h}$, ra'iyyatul imam manütun bil masla $\underline{b} a h$, and sadd alzariah as instruments of examination. 


\section{RESULTS AND DISCUSSION}

\section{The Concept of Legal Competence in Islamic Law}

As discussed, all Islamic scholars have agreed that none of the men and women could marry before both of them reach the bälig phase (H. Disemadi, Al-Fatih, \& Yusro, 2020). Despite this agreement, there were many different opinions on how old a person should be to reach the state of balig. Marrying before bälig is considered underage marriage, and it is called al-nikeāh al-sagir (Maisarah, Afrizal, Zulfahmi, Mauliza, \& Murni, 2019).

The term bälig has become a stressing point in Islamic legal competence. This phase is the stage of taklif, which means all who reach this point will be eligible to take legal action and is usually called as mukallaf. However, not all persons in this stage are considered sinful or rewarded due to their actions. Muhammad (PBUH) stated that qalam (the pen) is uplifted from three circumstances: insane persons until they gain their sane, sleeping persons until they awaken, and children until they reach puberty. So, besides physical maturity, legal competence has been associated with human appropriateness to do their legal acts. In the marital case, Quran (4:6) has placed different words other than puberty: rusydan (sound of judgment). While in general, Islam's legal eligibility is partitioned into two competencies: Abliyatul Wujūb and Abliyatul Adä' (Mohd \& Kadir, 2019; Nahrowi, 2016).

In Islamic legal theories, the term of legal competence is usually found in almahkum 'alaih discussion. It is the study of human actions measured by Allah's law. What people do is in conjunction with two requirements: (1) understanding the commandments' (khitäb) of legal imposition (taklifj); and (2) having proper legal competence (abliyah). The understanding of the first requirement is through the functioning of the mind. By using it, people will know and understand what they will do or not do. While the mind is a non-physical thing (al-umür al-khafiyyah), Sharia has emphasized that human senses acknowledge puberty (al-buligg) in mind. It is the usedword to know when people could understand between right and wrong or between beneficial and detrimental in a proper and perfect sense. Those who are unable to use the mind properly is are properly not to do their legal action. As mentioned earlier, three are included in this incompetence: crazy people, sleepers, and children. In other narration, Muhammad (PBUH) added unconscious people (Zuhaili, 1999).

Abliyatul Wujüb is legal eligibility intended for people who deserve others' rights and do the obligation acts toward them. The major point of this competence is al-bayāh (the life); so as long as we have our soul preserved, this competence will exist. Comparatively, Abliyatul $A d \vec{a}$ ' is people's competency in their legal consideration of every act. Different from previous abliyah, this competency is indicated in tamyiz, (the age of discernment) (Zaidan, n.d.).

The two terms above also could be described alse as receptive legal capacity $($ Abliyatul Wujüb) and active legal capacity (Abliyatul Adā). In each of those 
competencies, it has perfect (kämilah) and imperfect (nāqisah) eligibility (Mohd, Nik Mahmod, Muhammad, Amuda, \& Salleh, 2018). Those divisions are seen from human life phases, from when we were born until our death. Islamic law has constructed these stages to separate child and adult in terms of their responsibilities toward their actions. The imperfect receptive legal capacity is in fetus period, in the womb of the mother. It is because the embryo only receives limited rights such as inheritance and testament/will, as long as the fetus is born alive. After an embryo becomes a baby, the receptive legal capacity turns to be perfect as the baby lives until death. The status of legal capacity turns to be active when the child reaches the age of discernment (mumayyiz), the age when the child could differentiate the good and bad. It has been a common sense in Islamic tradition that age of mumayyiz is at seven years old based on the Muhammad's (PBUH) education guidance on performing șalah (pray). However, this active competency is still imperfect until the child reaches the age of puberty. The phase of puberty is the harbinger of adulthood, the phase in which a person not only know good and bad, but beyond all of that. Thus, adulthood represents the final phase of legal competency, Abliyatul Adè' Al-Kämilah (perfect legal competence) (Anwar, 2010).

Table 1. The Concluded-Periods of Islamic Legal Competence (Anwar, 2010;

Muqaddam, 2016)

\begin{tabular}{|c|c|c|}
\hline \multicolumn{2}{|c|}{ Legal Competences } & Periods \\
\hline Abliyatul Wujūb & Imperfect (nāqis $a h)$ & Fetus period \\
\hline & Perfect (kämilah) & $\begin{array}{l}\text { Birth period to the phase of children and } \\
\text { so forth until death }\end{array}$ \\
\hline \multirow{2}{*}{$\begin{array}{l}\text { Abliyatul Adaे' } \\
\text { (Active) }\end{array}$} & Imperfect (nāqis $\underline{s} a b)$ & The tamyir phase \\
\hline & Perfect (kämilab) & $\begin{array}{l}\text { Bälig phase biologically and rusydan } \\
\text { psychologically }\end{array}$ \\
\hline
\end{tabular}

In a marital context, they who are eligible enough to marry someone are those who reach the perfect Abliyatul $A d \bar{a}$ '. It is because this phase portrays a human as a complete legal person bearing full responsibilities for their legal actions. Judging from the habitual aspect, especially in Indonesia, this phase is estimated at 18 or 19 years old. So, when people have turned 18 and entered the age of 19, men and women will have complete responsibilities for their actions. The minimum age in exact number, based on Islamic scholars' various opinions, has become prominently urgent. Thus, as a formal institution to enforce the laws, the government has the right to decide the limitation of legal age concerning marriage. 


\section{The Legal Age Limitation in Marriage: Its Urgencies and Analysis}

Marriage is promoted to cover the human's desire for sexual intercourse. It could be seen in the definition of marriage in Islam. The meaning referred to two terms in Fiqh, both are nikäh $\underline{\text { and }}$ zawäj. Those two words mean al-wat $u$ or sexual intercourse. The terms defined as a legal agreement permit the two couples (men and women) to have sexual pleasure using the word inkāh or tazwij. In the usual ceremony, the bride guardian (waliy) would say ankabtuka or qawwajtuka, and the male (the groom) would answer qabiltu nikeähaba wa tazwijabaj. Through that legal contract, the bride and the groom have permission to engage in sexual intimacy, which is formerly prohibited (Riyani, 2016).

Engaging in sexual intercourse within a legal marital relationship is only practiced by those who reach puberty and maturity. Al-Bulug in Islamic law is required to show that the marriage relationship is not a mere sexual interaction between spouses but social commitment between families. The criteria of rusydan within al-bulig are also a prime factor for people's readiness to climb to higher social commitment responsibilities. Thus, many Islamic countries have tried to interpret the legal age of their people. The interpretation itself is based on the nation's self-characteristics, formed by people's local customs (Asrori, 2015). It indeed leads to the diversity of the laws on the minimum age of legal competence for marriage.

There are at least three relationships between the legal age and several factors of marriage. The first relation is between age and physiological factors. Second, it is the connection to the psychological aspect. The last is between age and social-economic readiness or social maturity (Latief, 2016).

The first relation connects the period with puberty biologically; in biology it refers to nocturnal emission (wet dream) for the male and menstruation for the female. In comparison, the second relation involves the age with the readiness of spouses on their new status. After the marriage, they will live separately from their parents and become new parents when they have children. How becoming father and mother to their son or daughter will determine the marriage's foundation. In a wider scope, the readiness of social maturity should be well-prepared. It is the interaction between husband and wife internally that links them to other families within society.

The Indonesian government has a shifting history regarding the legal age regulation, especially on marriage. The first regulation is placed in two rules: The Marriage Act No. 1 of 1974 and Islamic Law Compilations (19 for males and 16 for females). The two first regulations are then amended by The Marriage Act No. 16 of 2019, and it considers the age of 19 between males and females, respectively. These regulations attempt to conceptualize the standard legal competence in the interest of the people.

Many factors lead to the conclusion that the legal age of marriage is 19 years old. The health factor usually comes at the first insight and is typically referred to as the 
women's side. This health issue is linked to female fertility, which gives her the possibility to get pregnant. It is common and natural that pregnancy happens through sexual intercourse between men and women. Thus, many have agreed that this copulation will endanger underage women. because of the immature reproductive organ and unreadiness to bear infant(s) within the minimum weight of 2,500 grams. Others have added that sexual penetration would cervical cancer (Mustofa, 2018).

Factually, the disparity of the legal age of marriage around the world is not in far difference. It is still in a range of 17-20 years. Additionally, the range is also in the classical conclusion of many Islamic scholars a long time ago. Despite these varieties, the Indonesian government's determination to set the legal age could be analyzed through several formulations in Islamic law. Some of these formulations could be investigated from maslabah, sad al-zariah, and the Islamic legal maxim that states tasarruf al-imām 'ala al-ra'iyyah manūtun bil maslabah.

\section{The Maslahah Concept}

The maslabah term could refer back to what Al-Ghazali said on it. In his AlMustasfa, he noted that maslabab is the preservation of five Sharia's objects, preserving faith/religion, soul, mind, property, and offspring (Ghazali, n.d.; Lobah, 2016)(H. S. Disemadi, 2019)(H. Disemadi et al., 2020). As long as these five are preserved, it will be beneficial; otherwise, it is harmful. Analyzing the limiting of legal age through the maslabah concept means describing five objects of Sharia with marital age.

Setting the limit of marital age parallels what Al-Quran has categorized as rusydan (sound of judgment). In the rusydan period, humans could deliver their readiness to dive into a serious duty of marriage, that is, to properly practice the religion and educate it within the family. The age of rusydan would be practical and broadly announced in society at a specific period that the Indonesian government has concluded at 19 years old. This minimum limit is due to the psychological maturity between couple (Wahid, 2019). The psychological immature will lead to their willingness to do their sacred duty to practice religion more, especially their desire to educate their children. So, the age limit of marriage set by the government is intended to open the maslabah broadly. Thus, people would be more religious in their manner. When the people are religious enough, they would be assets of the country's development.

Preservation of soul in controlling the marital age is related to the statistical figures of mother's mortality after giving their first birth. The females within the age of 10-14 years are at risk of death, five times as high as those in the 20-24 age group. The risk doubles within the age of 15-19 years. Not only is it life-threatening for mothers, but it also threatens their infants. Babies born to mothers before the age of 20 have mortality risk two times as high as those born to mothers age 20 and above (Blaser, 2016; UNICEF, 2005). So, based on the researched cases, the deduction of age 19 for legal marriage in Indonesia is within the range of maslabah. It is is intended to prevent the death risk of the mothers and their infants. Thus, the human soul or their life would 
be well preserved, and the chance to sustain the country's development goals is more likely to be prepared.

The mind and assets in the context of marital age are closely related with how the couple would be socially prepared as they would construct and develop their mind in a wider scope of life. It is like preserving the religion; the couples need to understand how their family's future is for example, educating each other, educating their children, working hard to get enough income, and preparing their children's future economy and such things. This mind and economic preparation need to be prepared for achieving a golden life within the family to contribute to the country's development goals. So, setting the age of 19 between males and females is more reasonable than under 19 years old.

Last but not least, protecting the offspring is another essential point in this context. It is merely that previous objects of Sharia are in line with this object. By protecting the religion, the family would be in the best cooperation in their society and economic life. Piloting the family using the religious concept would ease the family's mind. It all leads to the excellent preparation of their future heirs. In this study, the line of mashlabah is quite clear that the Indonesian government attempts to project the quality of its people to participate more in the country's development.

\section{The Islamic Legal Maxim: Tasarruful Imām 'alar Ra'iyyah Manūthun bil \\ Mașlahah}

Based on the maslabah perspective, setting the legal age of marriage should be a government concern. Islamic law has one legal maxim related to what the government should pay attention to its people. It stated that tasarruful imäm 'alar ra'iyyah manūtun bil mașlabah (i.e., the leader's concern to his people should depend on people's interest). It means that the imam, the president, and other authorities are bonded to their people through wise decisions. The leader is the people's representative, so it is the relevant attitude when the leader sees through the people's advantages as a whole (Abdurrahman Al-Mubrid, $1432 \mathrm{H}$ ).

The above legal maxim is one of the Islamic theorems in public policy that many Islamic jurists has have used in their legal deduction. In many sources, this legal maxim has various texts with the same meaning. However, the one who introduced this legal maxim with the text of tasarruful imàm 'alar ra'iyyah manüthun bil mașlabahah is Badruddin Muhammad ibn Bahadir Al-Zarkasyi Al-Syafi'i (d: 793 H). It then has famously been used by other Islamic Scholars such as Jalaluddin Abdurrahman Al-Suyuthi Al-Syafi'i (d: $911 \mathrm{H}$ ). It has been clear that mașlabab is the core of the policy. Without the mașlabah the government policy would jeopardize the relationship between policy makers and the people (Ibn Misyari Al-Ghamidi, $1430 \mathrm{H}$ ).

So, the maslabah considers that setting legal marital age is the government's responsibility. By inventorying the maslabah of the minimum age, the reflection of age 19 could be the right decision for Indonesian people. The effort of recognizing the 
new legal age in marriage is shown through the amendment of The Marriage Act No. 1 of 1974 . Act No. 1 of 1974 stated the different minimum age between men and women. The male must reach the age of 18 while the female is at the age of 16 . By arranging the new minimum age, as set forth in The Marriage Act No. 16 of 2019, the government has tried to accommodate the mashlabah to minimalize any potential harm, especially when it endangers women and their infants.

\section{The Sadd Al-Zarīah Concept}

One of the Islamic legal source to reach legal deduction is sadd al-zariah. The Islamic Jurist who introduced this legal source is Malik ibn Anas, whose legal thought then developed into one of prominent Islamic school: Maliki Mazhab. It has two combined-words: sadd and al-zariah. The word of sadd refers to cover or block, while the al-zariah means the intermediary. Both paired-words as are defined as blocking something that is originally permissible, but for convincing reason, it leads to prohibited matter. This concept aims to restrict an access to any likelihood that could spark matters that are prohibited in sharia. The opposite of this source is fat $\underline{\text { al }}$-zariah, which means opening the intermediary which leads to permissible things (Rokan, 2020; Salleh, Kashim, Adnan, Ghani, \& Jamsari, 2019). This restriction is meant for the interest of all (Al-Farat, 2003; Fentiningrum, 2017).

The considered-age of 19 for marriage is deducted to close the vulnerabilities that could occur in the underage marriage. Thus, using this concept legal age limit in marriage is related with the maslabah itself. So, the prohibition for marrying before the considered-age is no other than to prevent the current and actual harms. Sharia's flexibility with unstated legal age encourages us to reflect on how we cross-relate between bälig, rusydan, and age with recent social problems that affect the human's maturity. Thus, via the three Sharia concepts, the legal policy would correspond the entire benefit for the people.

\section{CONCLUSION}

Marriage is a common word that echoed and heard in every culture and religion. It then religiously commands every person in the world to obtain the fundamental need for human relations. Through Muhammad's teachings, Islamic law coordinates this religious activity with the maturity readiness of each Muslim. Based on the Islamic legal competence concept, the all-legal activities would be synchronized and harmonized; to do what is right and put aside the prohibitions. Thus, in male-female interaction, the concept restricts the haphazard of immature marriage or sexual intercourse without marital ties, which Islamic law stands against.

The factual issues of underage marriage and potential risks may lead to the limitation of the legal age of marriage. With its most Muslim populated-country, Indonesia regulates two laws for limitation of marital age, where the former requires a person to be at least 19 and 16 years old to get married for male and female 
respectively. It then was revised to the age of 19 , for both sexes as to indicate maturity in both men and women. The triangle concept: maslabah, ra'iyyatul imam manütun bil maslabah, and sadd al-zari'ah, implies that the consideration of this legal age is wellmeasured. This triangle concept is suggested to be compulsory instruments employed to regulate and propose the laws. It is nothing but to give the people a chance to properly shape their maturity that armors them against recent socio-economic problems.

\section{REFERENCES}

Abdurrahaman Al-Mubrid, M. A. A. (1432). Al-Tatbiqat Al-Fiqbiyyah Liqa'idab: Tasarruf Al-Imam 'Ala Al-Ra'iyyah Manutun bil Mashlabah fi Kitab Al-Qada: AlMa'had Al-'Ali lil Qadza.

Al-Asqalani, A. bin A. bin H. (n.d.). Fathul Bari (A. Q. S. Al-Hamad, Ed.). Riyadh: Maktabatul Malik Fahd Al-Wataniyah.

Al-Farat, Y. A. (2003). Al-Tatbiqat Al-Mu'ashirah li Sadd Al-Drari'ah. Cairo: Darul Fikri Al-'Arabi.

Anggito, A., \& Setiawan, J. (2018). Metodologi Penelitian Kualitatif(E. D. Lestari, Ed.). Sukabumi: Jejak.

Anwar, S. (2010). Hukum Perjanjian Syariab: Studi tentang Teori Akad dalam Fikih Muamalat (2nd ed.). Yogyakarta: Pustaka Pelajar.

Asrori, A. (2015). Batas Usia Perkawinan Menurut Fukaha dan Penerapannya dalam Undang-. Al-'Adalah, 12(4).

Badan Pusat Statistik. (2017). Perkawinan Usia Anak di Indonesia 2013-2015. Jakarta.

Badan Pusat Statistik. (2020). Pencegahan Perkawinan Anak: Percepatan yang Tidak Bisa Ditunda. Jakarta.

Blaser, S. J. (2016). Child marriage in Indonesia. In Unicef.

Disemadi, H., Al-Fatih, S., \& Yusro, M. (2020). Indonesian Children Protection against Commercial Sexual Exploitation through Siri Marriage Practices in Maqashid Al-Shariah Perspective. Brawijaya Law Journal, 7(2), 195-212. https://doi.org/10.21776/ub.blj.2020.007.02.04

Disemadi, H. S. (2019). Adultery Child Status In Islamic Law And In The Civil Code. Legal Standing: Jurnal Imu Hukum, 3(2), 20-31. https://doi.org/10.24269/ls.v3i2.1877

Fentiningrum, H. (2017). Batasan Usia Pernikahan dalam Perundang-Undangan di Indonesia Perspektif Sadd Al-Dari'ah. Istidlal: Jurnal Studi Hukum Islam, 4(1), 8495.

Ghazali, A. H. (n.d.). Al-Mustashfa fi Ushul Al-Syariah (H. bin Z. Hafidz, Ed.). Medina.

Hori, M., \& Cipta, E. S. (2019). The Purpose of Marriage in Islamic Philosophical Perspective. Journal of Islamicate Studies (JoIS), 2(1), 51.

Ibn Misyari Al-Ghamidi, N. I. M. (1430). Qā’idah Al-Tașarruf 'alar Ra'iyyah Manūṭun bil mașlahah. Majallah Jāmi'ah Umm Al-Qurā Li 'Ulum Al-Syariah Wa Al-Dirasat Al-Islamiyah, 46.

Irwansyah. (2020). Penelitian Hukum: Pilihan Metode \& Praktik Penulisan Artikel (A. Yunus, Ed.). Yogyakarta: Mirra Buana Media. 
Kamarusdiana, \& Sofia, I. (2020). Dispensasi Nikah Dalam Perspektif Hukum Islam, Undang-Undang Nomor 1 Tahun 1974 dan Kompilasi Hukum Islam. Salam; Jurnal Sosial \& Budaya Syar-I, 7(1), 49-64.

Khoiruddin, H., Rohimin, R., \& Athoillah, M. A. (2019). Historical Socio Analysis in the Interpretation of the Quran: Case Study of Legal Verses. Esensia Jurnal IlmuIlmu Ushuluddin, 20(2), 199-208.

Latief, M. N. H. (2016). Pembaharuan Hukum Keluarga Serta Dampaknya Terhadap Pembatasan Usia Minimal Kawin dan Peningkatan Status Wanita. Jurnal Hukum Novelty, 7(2), 196. https://doi.org/10.26555/novelty.v7i2.a5467

Lobah, J. (2016). The Islamic Principle of Maslaha as Practical Wisdom for Human Development. In R. Schmidpeter (Ed.), Cultural Roots of Sustainable Management (pp. 145-151). https://doi.org/10.1007/978-3-319-28287-9_11

Maisarah, Afrizal, Zulfahmi, Mauliza, F., \& Murni, F. (2019). Minimum Marriage Age: Study of Fiqh of Four Madhabs. Britain International of Humanities and Social Sciences (BIoHS) Journal, 1(2), 149-158. https://doi.org/10.33258/biohs.v1i2.46

Mohd, A., \& Kadir, N. A. (2019). Minimum Age of Marriage Under Islamic Law and the Islamic Family Law (Federal Territories) Act 1984: A Preliminary Study on the Ideal Age of Marriage in Malaysia. Al-Shajarah Journal of Islamic Thought and Civilization of the International Islamic University Malaysia, 24(2), 239-266.

Mohd, A., Nik Mahmod, N. A. K., Muhammad, A. A., Amuda, Y. J., \& Salleh, M. C. M. (2018). Child Labor Under Islamic Law (The Shari'ah): An Overview. AlShajarah Journal of Islamic Thought and Civilization of the International Islamic University Malaysia, 23(2).

Muqaddam, S. (2016). Al-Abliyyah wa Atsaru Takhallufiba fi Qadhaya Syu un Al-Usrah baina Al-Figh Al-Islami wa Qawanin Al-Usrah Al-Maghribiyyah. Universite Mohamed Boudiaf - M'sila.

Mustofa, K. N. (2018). Provisions of Minimum Age of Marriage in Indonesia: Amendments Efforts and Responses. Asy-Syir'ah, 52(2), 289-312.

Nahrowi. (2016). Penentuan Dewasa Menurut Hukum Islam dan Berbagai Disiplin Hukum. Kordinat, 15(2), 253-274.

Riyani, I. (2016). The Silent Desire: Islam, Women's Sexuality and the Politics of Patriarchy in Indonesia. University of Western Australia.

Rokan, M. K. (2020). The Theory of Zariah Legal Movement and It's Application in Market Law in Indonesia. Ijtimä'iyya: Journal of Muslim Society Research, 5(1), 69-83. https://doi.org/10.24090/ijtimaiyya.v5i1.3949

Salleh, A. D., Kashim, M. I. A. M., Adnan, N. I. M., Ghani, N. A. R. N. A., \& Jamsari, E. A. (2019). Theory and Application of Sadd al-Dhara'i‘ (Blocking the Means) in Shafi iyya School. International Journal of Academic Research in Business and Social Sciences, 9(1), 724-737. https://doi.org/10.6007/IJARBSS/v9-i1/5475

Seise, C. (2019). Re-Thinking the Age of Adolescence - An Islamic Perspective. IIUM Journal of Religion and Civilisational Studies (IJECS), 2(2), 206-213.

Shahar, M. A. (2018). The Role of Modern Medicine in Clarifying Definitions in Islamic Jurisprudence (Ta'rifaats fi al-Fiqh). IIUM Medical Journal Malaysia, 17(3), 113-118.

Sialvi, A. R. S. (2018). Status and Necessity of Second Marriage in Islam. Al-A'jar, 2(2), 1-10. 
Sitorus, I. R., \& Yusmita, Y. (2020). The Age of Marriage on Interdisiplinary Islamic Law Perspectives. Jurnal Ilmiah Mirani: Wacana Hukum, Ekonomi Dan Keagamaan, 7(1), 1. https://doi.org/10.29300/mzn.v7i1.3137

Sorokowski, P., Randall, A. K., Groyecka, A., Frackowiak, T., Cantarero, K., Hilpert, P., ... Sorokowska, A. (2017). Marital satisfaction, sex, age, marriage duration, religion, number of children, economic status, education, and collectivistic values: Data from 33 countries. Frontiers in Psychology, 8(JUL), 1-7. https://doi.org/10.3389/fpsyg.2017.01199

UNICEF. (2005). Early Marriage A Harmful Traditional Practice A Statistical Exploration 2005.

Wahid, N. (2019). Historisitas dan Tujuan Aturan Umur Minimal Perkawinan dalam Perundang-Undangan Keluarga Islam di Indonesia. Volksgeist, 2(2), 163-177. https://doi.org/10.24090/volksgeist.v1i2.2822

Zaidan, A. K. (n.d.). Al-Wajizfi Ushulil Figh. Beirut: Muassasah Qurtubah.

Zaki, A. A. (2017). Konsep Pra-Nikah dalam Al-Qur'an (Kajian Tafsir Tematik). Jurnal Bimas Islam, 10(1), 155-192.

Zaman, N., \& Hashmi, M. (2019). Woman's Marriage Age in Shari'‘ ah: Traditional and Modern Approaches. Ma'arif-E-Islami (AIOU), 18(2).

Zarean, M., \& Barzegar, K. (2016). Marriage in Islam, Christianity, and Judaism. Religious Inquiries, 5(9), 67-80.

Zuhaili, W. (1999). Al-Wajiz fi Ushulil Fiqh (1st ed.). Beirut: Darul Fikr. 